\title{
Characterization of Philippine natural bentonite
}

\author{
Eleanor M. Olegario ${ }^{1}$ and Mon Bryan Z. Gili ${ }^{2, *}$ (D) \\ ${ }^{1}$ Department of Mining, Metallurgical and Materials Engineering, University of the Philippines Diliman, Quezon City, \\ Philippines, and ${ }^{2}$ Department of Science and Technology, Philippine Nuclear Research Institute, Quezon City, Philippines \\ *Corresponding author. Email: gilimonbryan@yahoo.com
}

(Received 17 June 2021; Revised 14 July 2021; Accepted 15 July 2021)

\begin{abstract}
Philippine natural bentonite is characterized using X-ray diffractometer (XRD), scanning electron microscope (SEM), chemical analysis, thermogravimetric-differential scanning calorimetry (TG-DSC), and Fourier transform infrared (FTIR) analysis. The cation exchange capacity (CEC) was also measured. XRD shows that the mineral is composed primarily of mordenite, hectorite, and montmorillonite. SEM shows the flaky and porous structure of the bentonite powder. Chemical analyses show that $\mathrm{SiO}_{2}$ (47.90 wt\%) and $\mathrm{Al}_{2} \mathrm{O}_{3}(14.02 \mathrm{wt} \%)$ are the major components of the clay. TG-DSC shows that the mineral contains $15.55 \%$ moisture. IR transmittance spectrum shows the common vibration bands present in the sample which include $\mathrm{O}-\mathrm{H}$ stretching of inter-porous water, symmetric and asymmetric stretching of hydroxyl functional groups, asymmetrical stretching of internal tetrahedra $(\mathrm{O}-\mathrm{Si}-\mathrm{O}$ and $\mathrm{O}-\mathrm{Al}-\mathrm{O})$, symmetrical stretching of external linkages, and so on. The measured CEC were found to be 91.37 and $43.01 \mathrm{meq} / 100 \mathrm{~g}$ according to the ammonium acetate method and barium acetate method, respectively.
\end{abstract}

Key words: bentonite; FTIR; montmorillonite; TG-DSC; XRD

\section{Introduction}

Clay minerals are used in different applications owing to their high cation exchange capacity and high surface area. Bentonite clay consists mainly of crystalline clay minerals belonging to the smectite group, which are hydrous aluminum silicates containing Fe and $\mathrm{Mg}$ as well as either $\mathrm{Na}$ or $\mathrm{Ca}$. Bentonite forms from the alteration of volcanic glass to clay minerals which requires hydration (combination or taking up of water) and a loss of alkalis, bases, and possibly silica, with the preservation of the textures of the original volcanic glass. Bentonite is mainly composed of montmorillonite (Uddin, 2008) and other minor nonclay minerals, in which it has an overall negative charge either in tetrahedral sheet or octahedral sheet form. Montmorillonite, a smectite clay mineral composed of three layers, has a 2:1 ratio of $\mathrm{Si}^{4+}$ tetrahedral to $\mathrm{Al}^{3+}$ octahedral sheets. The interlayer, formed by one octahedral sheet sandwiched between two silica tetrahedral sheets, between its units is composed of positive cations and water molecules making them excellent supporting materials for nanoparticles (Motshekga et al., 2013).

The structure of smectite minerals allows multiple positional or elemental substitutions within its lattice. Such substitutions induce a deficiency in net positive charge, which is thereby balanced by exchangeable cations (Olegario \& Felizco, 2017). The members of the smectite minerals are classified based on the species and location of the cations in the crystal structure. When trivalent cations occupy 
two-thirds of the octahedral sites, these minerals are called dioctahedral smectites which include montmorillonite, beidellite, and nontronite. When divalent cations occupy all three octahedral sites, these are called trioctahedral smectites. Examples of which are saponite, sauconite, and hectorite (Odom, 1984).

\section{Objectives}

This work is an extensive characterization of Philippine natural bentonite using various characterization techniques which include X-ray diffractometer (XRD), chemical analysis, scanning electron microscope (SEM), thermogravimetric-differential scanning calorimetry (TG-DSC), Fourier transform infrared (FTIR), and cation exchange capacity (CEC) measurements. Although there are already several studies on Philippine natural bentonite, most of which are centered on the applications of bentonite. Dahonog et al. (2019) studied the antibacterial activity of plasma-treated $\mathrm{Cu}$-bentonite nanocomposites. Olegario and Felizco (2017) investigated the structural properties of amorphous Philippine bentonite clay and its potential use for topical applications. In this study, the CEC was measured, and the $\mathrm{pH}$ was determined. Microbial analysis was done alongside the XRD characterization of the mineral. Taaca et al. (2019) assessed the antimicrobial and cytotoxic activities of ion-exchanged Ag-modified bentonite. Cruz and Diaz (2019) studied the adsorption of $\mathrm{Cu}$ (II) onto Fe(III)-modified montmorillonite. As stated, most studies revolved around the applications of Philippine bentonite. Therefore, there is a need to make a separate study on the characterization of the material. This work is much more comprehensive in terms of characterization techniques than the rest of the existing papers.

\section{Methodology}

Bentonite powder samples were provided by LITHOS Manufacturing, OPC. The bentonite was mined from Mangatarem, Pangasinan in Luzon, Philippines. The powder is finely ground with sizes ranging from 100 to $200 \mathrm{mesh}$. It has a brown to reddish color and has a true specific gravity of $<2.2$. The structure and crystallinity of the raw bentonite sample were analyzed using an XRD (Shimadzu XRD-7000) using $\mathrm{Cu}-\mathrm{K} \alpha$ radiation from $2^{\circ}$ to $70^{\circ} 2 \theta$. The morphology of the bentonite clay was examined using an SEM (Shimadzu SSX-550) with an acceleration voltage of $15.0 \mathrm{kV}$. Chemical tests were separately done to confirm the amount of each chemical component present in the Philippine bentonite samples. The thermal behavior and stability of the raw bentonite were investigated using DSC (TA Instruments DSC Q10) at a heating rate of $10.00^{\circ} \mathrm{C} / \mathrm{min}$ from room temperature up to $1,000^{\circ} \mathrm{C}$. The vibration bands present in the samples' transmittance spectrum were analyzed using an attenuated total reflectance FTIR (ATRFTIR) analyzer (Perkin Elmer FTIR Spectrometer) from 4,000 to $650 \mathrm{~cm}^{-1}$. Cation exchange capacity measurements were conducted using ammonium acetate and barium acetate methods.

\section{Results and Discussion}

\subsection{X-ray diffractometry}

Figure 1 shows the X-ray diffractogram of the raw bentonite sample used in this study. It can be observed that the sample is mainly composed of hectorite (amcsd 0015819) and montmorillonite (amcsd 0002868) from the smectite group and mordenite (amcsd 0003444) from the zeolite minerals. However, the amount of each component cannot be discerned as the peaks of each component overlap each other. Small amounts of nontronite (amcsd 0007180), and other minerals such as kaolinite (amcsd 0017947), feldspar (amcsd 0000436), and mica (amcsd 0000836) were also present in the sample. Calcite, cristobalite, and quartz, which are possibly carcinogenic (Modabberi et al., 2015) were not detected in the sample. The results agree well with the XRD patterns of the Philippine bentonite in previous studies (Olegario \& Felizco, 2017; Taaca et al., 2019). The bentonite sample used in the study share several common components with the Philippine natural zeolite reported in our previous studies as 


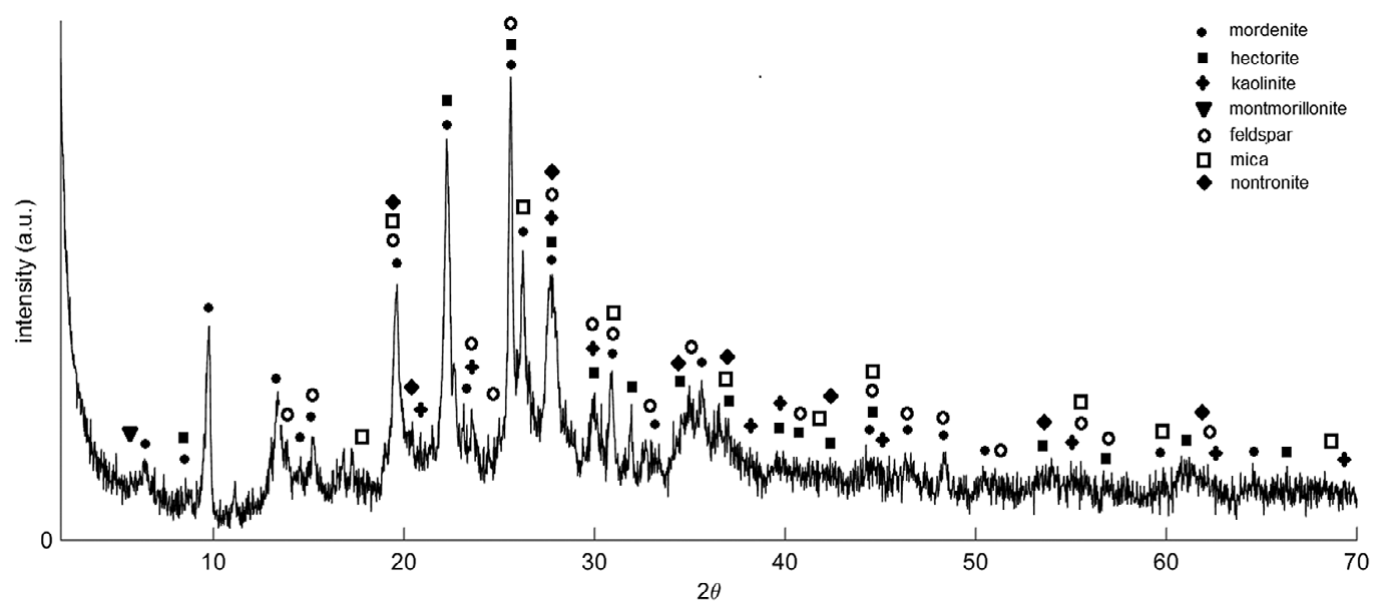

Figure 1. X-ray diffractogram of the raw Philippine natural bentonite.

Table 1. Chemical components of the Philippine bentonite based on chemical tests

\begin{tabular}{lll}
\hline Component & Weight\% & Analytical method \\
\hline $\mathrm{SiO}_{2}$ & 47.90 & Gravimetric \\
\hline $\mathrm{Al}_{2} \mathrm{O}_{3}$ & 14.02 & Titration \\
\hline $\mathrm{Fe}_{2} \mathrm{O}_{3}{ }^{a}$ & 7.54 & Flame-atomic absorption spectrometry \\
\hline $\mathrm{CaO}$ & 4.83 & Titration \\
\hline $\mathrm{MgO}$ & 1.59 & Titration \\
\hline $\mathrm{K}_{2} \mathrm{O}$ & 0.46 & Flame-atomic absorption spectrometry (by computation) \\
\hline $\mathrm{Na}_{2} \mathrm{O}$ & 0.33 & Flame-atomic absorption spectrometry (by computation) \\
\hline $\mathrm{H}_{2} \mathrm{O}$ & 10.71 & Gravimetric \\
\hline $\mathrm{LOI}^{\mathrm{b}}$ & 12.27 & Gravimetric \\
\hline $\mathrm{Total}^{\mathrm{a}}$ & 99.65 & \\
\hline $\mathrm{Comb}$ & &
\end{tabular}

${ }^{\mathrm{a} C}$ Computed from Fer.

${ }^{\mathrm{b}}$ Loss on ignition.

they are mined from the same area in Mangatarem, Pangasinan (Gili \& Olegario, 2020; Gili, OlegarioSanchez, \& Conato, 2019; Gili, Pares, et al., 2019).

\subsection{Chemical analysis}

Various chemical analyses such as gravimetric, titration, and flame-atomic absorption spectrometry were done to verify and determine the components of the raw Philippine bentonite. The chemical composition, according to the supplier's chemical analysis report from an independent laboratory (Chemistry Laboratory of the Mines and Geosciences Bureau, Department of Environment and Natural Resources, Philippines) is given in Table 1 . The most abundant components were silica and alumina which comprise $47.90 \%$ and $14.02 \%$ of the total weight, respectively. It is worth mentioning that these two components determine the number of $\mathrm{Si}$ and $\mathrm{Al}$ present in the bentonite. $\mathrm{Si} / \mathrm{Al}$ ratio influences the efficiency of the material to adsorb cation or its CEC (Gili \& Conato, 2019). Normally, the lower the Si/Al ratio, the higher the maximum adsorption capacity, the greater the CEC. This means that the material might be a good adsorbent of heavy metals and other positively charged molecules as one of its many applications. It was 
then followed by ferric oxide which accounts for $7.54 \%$ and lime which is $4.83 \%$ of the total weight of the powder sample. $\mathrm{MgO}$ accounts for $1.59 \%$ of the total weight while $\mathrm{K}_{2} \mathrm{O}$ and $\mathrm{Na}_{2} \mathrm{O}$ are $0.46 \%$ and $0.33 \%$, respectively. The powder sample absorbs a considerable amount of moisture at 10.71 weight\%. The loss of ignition is around $12.27 \%$. This might probably be attributed to the volatile materials present in the sample such as organic matter which burns at elevated temperatures.

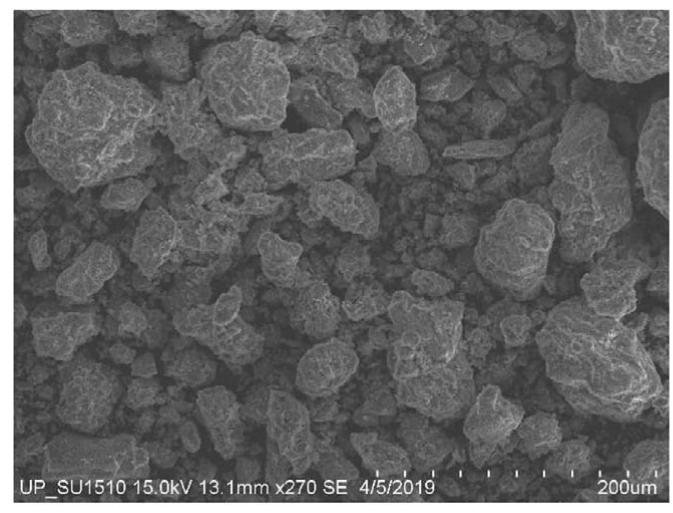

a

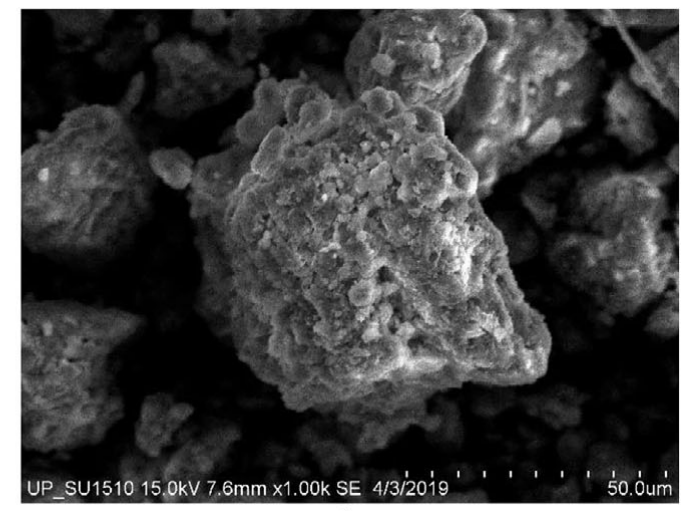

b

Figure 2. Scanning electron microscopy (SEM) images of the Philippine natural bentonite at different magnifications: (a) $270 \times$ and (b) $1,000 \times$.

\subsection{Scanning electron microscopy}

Figure 2 shows the SEM images of the raw Philippine natural bentonite. The powder samples are composed of particles of irregular size and shapes. Some particles agglomerate creating bigger particles. However, most particles are less than $50 \mu \mathrm{m}$ in size. At higher magnification, the powder is made up of particles with flaky and porous textures. The flaky and porous texture is advantageous as it gives the material a higher surface area which means higher chances of interaction for cation exchange and absorption purposes.

\subsection{Thermogravimetric-differential scanning calorimetry}

Figure 3 shows the TG-DSC curve of the Philippine bentonite. Three notable weight loss was recorded. The first one is a substantial weight loss occurring from room temperature up to $240^{\circ} \mathrm{C}$. The weight loss is equal to $15.55 \%$ which is attributed to the moisture content of the bentonite. The endothermic peak (minima) is centered at around $100^{\circ} \mathrm{C}$ which is the vaporization point of water. The second reduction in weight occurs at $240^{\circ} \mathrm{C}$ up to $500^{\circ} \mathrm{C}$ which recorded a further loss in weight of $3.51 \%$. This can be accounted to the evaporation of tightly bound water in the zeolitic components of the mineral (Olegario et al., 2017). Note that there is another endothermic peak at $485^{\circ} \mathrm{C}$ suggesting dehydroxylation of hydroxyl functional groups. Dehydroxylation involves the heating process through which the hydroxyl group $(\mathrm{OH})$ is released by forming a water molecule (Frost \& Vassallo, 1996). Finally, a weight loss of $2.13 \%$ which occurred at $500-1,000^{\circ} \mathrm{C}$ is due to the release of volatile materials. In total, the loss in weight of the bentonite after heating at $1,000^{\circ} \mathrm{C}$ is equal to $21.19 \%$ of the initial mass. Comparably, the thermogravimetric curve of the Philippine bentonite is almost the same as that of Philippine natural zeolite, which recorded an approximately $17 \%$ decrease in mass after heating at $1,000^{\circ} \mathrm{C}$ (Olegario et al., 2017). The two minerals are mined from the same site in Mangatarem, Pangasinan in Luzon Island, Philippines. 


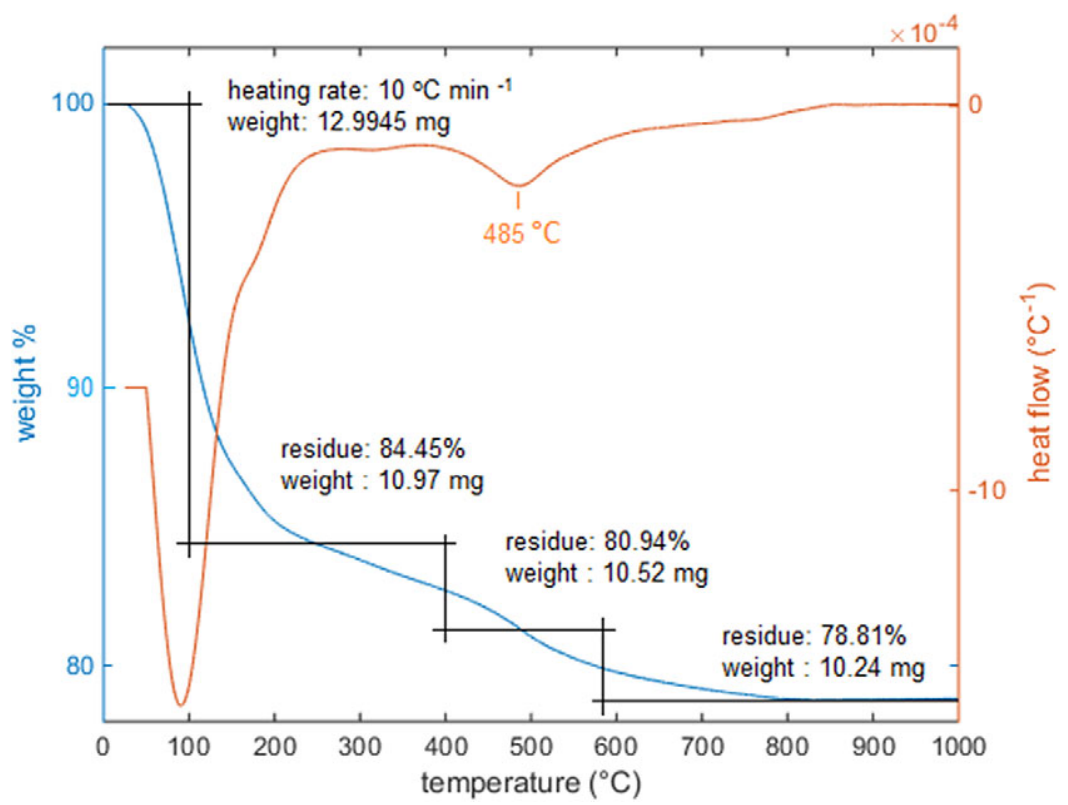

Figure 3. Thermogravimetric-differential scanning calorimetry curve of the Philippine bentonite.

\subsection{Fourier transform infrared analysis}

Figure 4 shows the infrared (IR) transmittance spectrum of the Philippine natural bentonite. The vibration bands present in the sample are as follows: the band at $3,622 \mathrm{~cm}^{-1}$ corresponds to the $\mathrm{O}-\mathrm{H}$ stretching of inter-porous water (Osonio \& Velasquez, 2018). The vibration bands at 3,392 and $2,987 \mathrm{~cm}^{-1}$ correspond to the symmetric and asymmetric stretching of hydroxyl functional groups (Prasetyp \& Soegijono, 2018). The bands at 1,632 and 1,414 $\mathrm{cm}^{-1}$ are attributed to the typical bending of $\mathrm{H}_{2} \mathrm{O}$ molecules attached to the surface of the zeolite (Karge, 2001; Osonio \& Velasquez, 2018), whereas $1,205,1,000,913$, and perhaps $876 \mathrm{~cm}^{-1}$ are due to the asymmetrical stretching of internal tetrahedra (O-Si-O and O-Al-O; Osonio \& Velasquez, 2018). The vibration band at $792 \mathrm{~cm}^{-1}$ is assigned to the symmetrical stretching of external linkages while the vibration groups at 748 and $688 \mathrm{~cm}^{-1}$ are due to the symmetrical stretching of internal tetrahedra. Note that the bands in the $600-800 \mathrm{~cm}^{-1}$ range are assigned to exchangeable cations (Olegario et al., 2017).

\subsection{Cation exchange capacity}

The Philippine natural bentonite was tested for CEC. According to the result of an independent experiment conducted by Lipa Quality Control Center, 001 J.P. Laurel National Highway, Purok 4, Brgy. Sico, Lipa City, Batangas 4,217, Philippines, the CEC of the bentonite is $91.37 \mathrm{meq} / 100 \mathrm{~g}$ using the ammonium acetate method. On the other hand, the measured CEC according to the barium acetate method is $43.01 \mathrm{meq} / 100 \mathrm{~g}$. There are several factors on why the two values are not equal. The disadvantage of the $\mathrm{Ba}(\mathrm{OAc})_{2}$ method seems to be associated with the low buffer capacity of the solution such that exchange acidity is not displaced (Pratt \& Holowaychuk, 1954). Ba(OAc) ${ }_{2}$ method was inefficient in the displacement of $\mathrm{H}$ ions (Hanna \& Reed, 1948). The low values for the $\mathrm{Ba}(\mathrm{OAc})_{2}$ procedure is probably more associated with exchangeable Al than with exchangeable $\mathrm{H}$ (Pratt \& Holowaychuk, 1954). The measured CEC values are much higher than natural clinoptilolite and other selected materials (Gili, Olegario-Sanchez, \& Conato, 2019). This means that the natural bentonite is a good candidate adsorbent for the sorption of heavy metals and other cationic pollutants in an aqueous environment. 


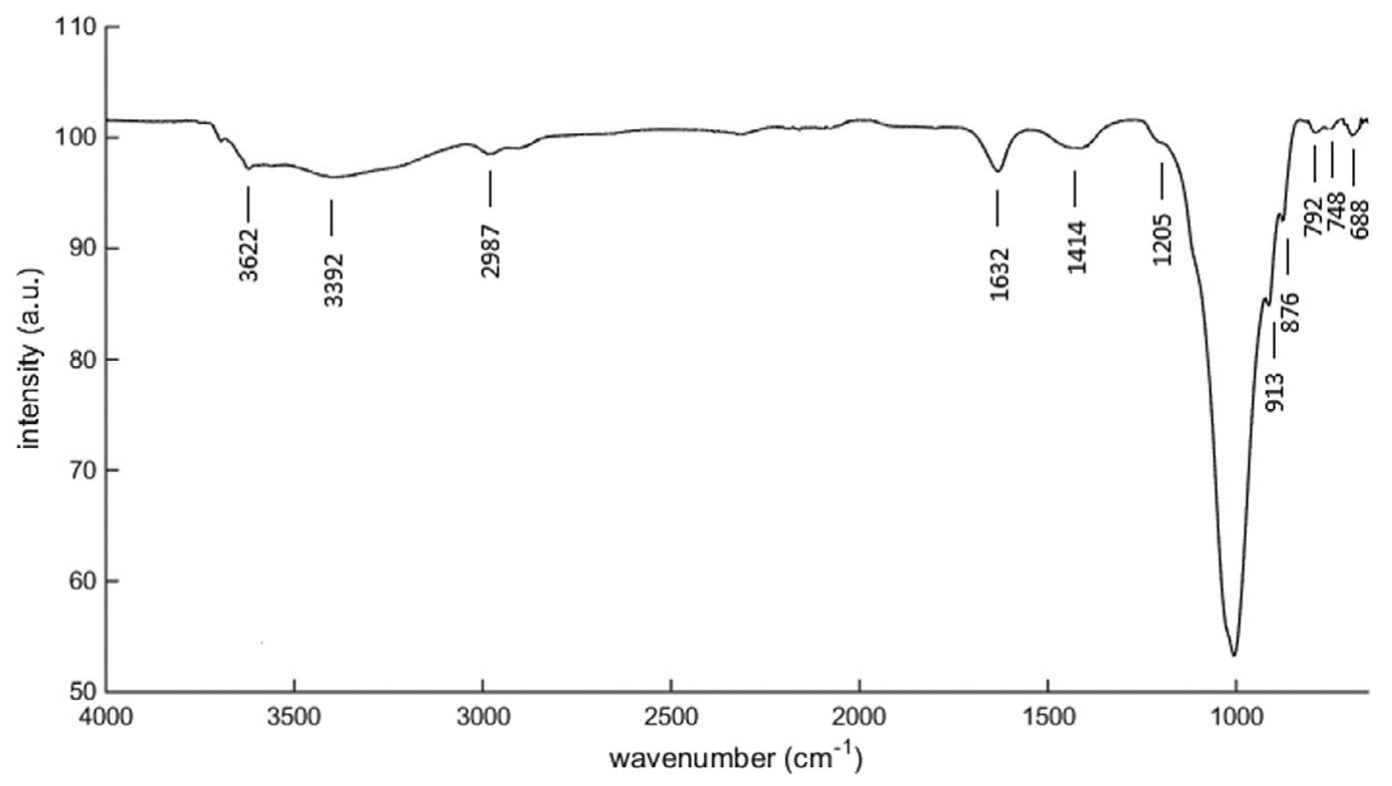

Figure 4. Infrared (IR) transmittance spectrum of raw Philippine natural bentonite.

\section{Conclusions}

The Philippine natural bentonite is composed primarily of mordenite, hectorite, and montmorillonite. Traces of kaolinite, feldspar, mica, and nontronite are also present in the clay mineral. It was found that the Philippine bentonite is composed mainly of silica (47.90 wt\%) and alumina (14.02 wt\%) according to chemical analysis. SEM images reveal that the powder is made of particles with flaky and porous morphology. TG-DSC shows that the bentonite contains a significant amount of moisture amounting to $15.55 \mathrm{wt} \%$ excluding the tightly bound water which accounts for $3.51 \%$ of the total weight of the bentonite. IR transmittance spectrum of the bentonite sample shows the common vibration bands present in bentonite samples. It was found that the CEC of the Philippine natural bentonite is 91.37 and $43.01 \mathrm{meq} / 100 \mathrm{~g}$ according to ammonium acetate and barium acetate methods, respectively.

Acknowledgments. The authors would like to thank Dr. Tsumotu Sato of the Environment Geology Laboratory under the Division of Sustainable Resources Engineering in Hokkaido University for the use of analytical equipment for the mineralogy and morphology of the bentonite minerals.

Authorship Contributions. M.Z.G. conceived and designed the study. M.Z.G. and E.M.O. conducted data collection, analysis, and interpretation. Both authors contributed to writing the article.

Funding Statement. This research was not funded by any agency, organization, or institution. However, the authors would like to thank the Applied Physics Research Section of the Philippine Nuclear Research Institute for its support in the conduct of the study.

Conflicts of Interest. The authors have no conflicts of interest to declare.

Data Availability Statement. The data that support these findings are openly available upon request to the corresponding author.

\section{References}

Cruz, J. K., \& Diaz, L. J. (2019). Adsorption of $\mathrm{Cu}(\mathrm{II})$ onto $\mathrm{Fe}(\mathrm{III})$-modified montmorillonite-kinetic, isotherm, and thermodynamic studies. IOP Conference Series: Materials Science and Engineering, 540, 012004. https://doi.og/10.1088/ $1757-899 \mathrm{X} / 540 / 1 / 012004$ 
Dahonog, L. A., Tugado, C. B., Olegario-Sanchez, E. M., \& Vasquez Jr., M. R. (2019). Antibacterial activity of plasma-treated Cu-bentonite nanocomposites. Journal of Physics: Conference Series, 1191, 012057. https://doi.org//10.1088/1742-6596/ 1191/1/012057

Frost, R. L., \& Vassallo, A. M. (1996). The dehydroxylation of the kaolinite clay minerals using infrared emission spectroscopy. Clays and Clay Minerals, 44, 635-651.

Gili, M., Olegario-Sanchez, E., \& Conato, M. (2019). Adsorption uptake of Philippine natural zeolite for Zn2+ ions in aqueous solution. Journal of Physics: Conference Series, 1191, 012042. https://doi.org/10.1088/1742-6596/1191/1/012042

Gili, M. B. Z., \& Conato, M. T. (2019). Adsorption uptake of mordenite-type zeolites with varying Si/Al ratio on $\mathrm{Zn} 2+$ ions in aqueous solution. Materials Research Express, 6: 045508. https://doi.org/10.1088/2053-1591/aafc08

Gili, M. B. Z., \& Olegario, E. M. (2020) Effects of $\gamma$-irradiation on the $\mathrm{Cu} 2+$ sorption behaviour of $\mathrm{NaOH}$-modified Philippine natural zeolites. Clay Minerals, 55(3), 248-255. https://doi.org/doi:10.1180/clm.2020.34

Gili, M. Z., Pares, F. A., Nery, A. L. G., Guillermo, N. R. D., Marquez, E. J., \& Olegario, E. M. (2019). Changes in the structure, crystallinity, morphology and adsorption property of gamma-irradiated Philippine natural zeolites. Materials Research Express, 6, 125552. https://doi.org/10.1088/2053-1591/ab6c8b

Hanna, W. J., \& Reed, J. F. (1948). A comparison of ammonium acetate and buffered barium chloride methods for determining cation-exchange properties of limed soils. Soil Science, 66, 447-458.

Karge, H. (2001). Verified syntheses of zeolitic materials. In Characterization by IR spectroscopy (69-72). Gulf Professional Publishing.

Modabberi, S., Namayandeh, A., López-Galindo, A., Viseras, C., Setti, M., \& Ranjbaran, M. (2015). Characterization of Iranian bentonites to be used as pharmaceutical materials. Applied Clay Science, 193-201, 116.

Motshekga, S. C., Ray, S. S., Onyango, M. S., \& Momba, M. N. B. (2013). Microwave-assisted synthesis, characterization and antibacterial activity of $\mathrm{Ag} / \mathrm{ZnO}$ nanoparticles supported bentonite clay. Journal of Hazardous Material, 262, 439-446.

Odom, I. (1984). Smectite clay: Mineral properties and uses. Philosophical Transactions of the Royal Society of London A, 311 391-409.

Olegario, E., Felizco, J., \& Mulimbayan, F. (2017). Investigation of the thermal behavior of Philippine natural zeolites. AIP Conference Proceedings, 1901, 070005.

Olegario, E., \& Felizco, J. C. (2017). Investigation of the structural properties of amorphous philippine bentonite clay and its potential use for topical applications. Key Engineering Materials, 737, 401-406.

Osonio, A., \& Velasquez Jr., M. (2018). Plasma-assisted reduction of silver ions impregnated into a natural zeolite framework. Applied Surface Science B, 432, 156-162.

Prasetyp, T., \& Soegijono, B. (2018). Characterization of sonicated natural zeolite/ ferrric chloride hexahydrate by infrared spectroscopy. Journal of Physics: Conference Series, 985, 012022.

Pratt, P. F., \& Holowaychuk, N. (1954). A comparison of ammonium acetate, barium acetate, and buffered barium chloride methods of determining cation exchange capacity. Soil Science Society of America Journal, 18, 365-368. https://doi.org/ 10.2136/sssaj1954.03615995001800040004x

Taaca, K. L., Dahonog, L., Argayosa, V., Rubio, R., \& Olegario, E. (2019). Assessment of antimicrobial and cytotoxic activities of ion exchanged Ag-modified bentonite. Materials Today: Proceedings, 16, 1782-1788.

Uddin, F. (2008). Clays, nanoclays, and montmorillonite minerals. Metallurgical and Materials Transactions A, 39, $2804-2814$.

Cite this article: Olegario EM, Gili MBZ (2021). Characterization of Philippine natural bentonite Experimental Results, 2, e25, 1-10. https://doi.org/10.1017/exp.2021.16 


\section{Peer Reviews}

\section{Reviewing editor: Dr. Mert Celikin}

University College Dublin, Mechanical and Materials Engineering, Dublin, Ireland, 4

This article has been accepted because it is deemed to be scientifically sound, has the correct controls, has appropriate methodology and is statistically valid, and has been sent for additional statistical evaluation and met required revisions.

doi:10.1017/exp.2021.16.pr1

\section{Review 1: Characterization of Philippine natural bentonite}

Reviewer: Dr. Masami Okamoto (D)

Date of review: 22 June 2021

(C) The Author(s), 2021. Published by Cambridge University Press. This is an Open Access article, distributed under the terms of the Creative Commons Attribution licence (http://creativecommons.org/licenses/by/4.0), which permits unrestricted re-use, distribution and reproduction, provided the original article is properly cited.

Conflict of interest statement. Reviewer has no competing financial interests to declare.

Comments to the Author: This paper describes the characterization of Philippine natural bentonite.

The topic is important in clay researcher. Other physical properties such as colour, density, hardness (Moh's scale), calcination temperature should be added.

Regarding references: there are 2 references for 2018, 3 references for 2019 and one for 2020 . These references will have merit to be presented.

\section{Score Card}

Presentation

3.0

Is the article written in clear and proper English? (30\%)

Is the data presented in the most useful manner? (40\%)

Does the paper cite relevant and related articles appropriately? (30\%)

Context

Does the abstract correctly embody the content of the article? (25\%)

Does the introduction give appropriate context? (25\%)

Is the objective of the experiment clearly defined? (25\%) 
Are the limitations of the experiment as well as the contributions of the experiment clearly outlined? (20\%) 


\section{Review 2: Characterization of Philippine natural bentonite}

Reviewer: Dr. Muhammad Abbas Ahmad Zaini i

Universiti Teknologi Malaysia

Date of review: 10 July 2021

(C) The Author(s), 2021. Published by Cambridge University Press. This is an Open Access article, distributed under the terms of the Creative Commons Attribution licence (http://creativecommons.org/licenses/by/4.0), which permits unrestricted re-use, distribution and reproduction, provided the original article is properly cited.

Conflict of interest statement. Reviewer declares none

Comments to the Author: Dear Authors,

Kindly address the following, and incorporate your responses into the manuscript:

1. Highlight the difference in the findings reported in the manuscript as opposed to the present similar work on Philippine bentonite. What is the research gap? How comprehensive is the present work? Cite related/relevant literature.

2. 'Spectra' is plural.

3. What are the advantages of having silica and alumina in bentonite? What are the possible direct applications related to this composition? Please discuss.

4. Discuss the dehydroxylation at $485 \mathrm{C}$. Which structure involved and why?

5. Why and how the magnitudes of CEC by the two methods are different? What are the advantages of having such CEC values and what do they infer? What are the possible direct applications related to this values? Cite relevant literature and discuss.

\section{Score Card}

Presentation

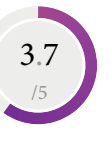

Is the article written in clear and proper English? (30\%)

Is the data presented in the most useful manner? (40\%)

Does the paper cite relevant and related articles appropriately? (30\%)

\section{Context}

Does the title suitably represent the article? (25\%)

Does the abstract correctly embody the content of the article? (25\%)

Does the introduction give appropriate context? (25\%)

Is the objective of the experiment clearly defined? (25\%)

Analysis

Are the limitations of the experiment as well as the contributions of the experiment clearly outlined? $(20 \%)$ 